Revista Aspas

ppgac - USP

Forma Livre

\title{
RASTEJAR COMO ATO TERRORISTA: UM CORPO DESOBEDIENTE RASGANDO CALÇADAS DO GÊNERO
}

\section{Princesa Ricardo Marinelli}

Princesa Ricardo Marinelli

Princesa Ricardo Marinelli está bem bicha. Bicha orgulhosamente bizarra. Artista da dança, Terrorista de gênero. Licenciadx em Educação Física e Mestrx em Educação pela UFPR. Doutorandx em Performances Culturais na UFG. Professorx do curso de Dança da FAP-UNESPAR. Quer mesmo é tocar fogo no antigo e no novo normal. 
Lembro muito nitidamente de estar com o corpo esparramado no chão gelado de uma sala de ensaio, olhando para as imperfeições do piso, olhos vertendo água. Nem chamo de choro. Já tinha parado de chorar, mas o corpo continuava vertendo água. Às vezes perdidx da percepção de alguns pedaços do corpo, que pareciam infiltrar-integrar o chão por conta do peso. De um peso que, de mãos dadas com a gravidade, parecia tornar o mundo uma atmosfera muito mais densa do que a habitual. Tudo sem nenhuma dramatização, sem representação, sem desejo. Só a descrição de um estado, como se naquele momento o corpo só pudesse existir daquela maneira. E eu estava lá, naquele chão, para ensaiar. Para criar. Para dançar. Para inventar mundos.

Era 2010 e semanas atrás eu havia sido despertadx com a notícia de mais dois ataques violentos a travestis em Curitiba. Circunstâncias assustadoramente cruéis, até para os padrões da conservadora capital paranaense. Infelizmente os ataques só confirmavam as estatísticas, nada de novo. Mas dessa vez eu estava perto, dessa vez o corpo que eu sou ressonava a violência de outro jeito. Em meio às minhas próprias revoluções identitárias diárias, o corpo reagiu como nunca havia reagido a situações parecidas. "Princesa Ricardo Marinelli", a existência caoticamente fora do binário que se apresenta aqui nesse 2021, lá era um projeto, um desejo firme, mas conflituoso. X Princesa que se forjava já nascia marcadx por sangue, gritos, ácido, hospital, morte.

Era 2010 e eu estava no meio de um processo de criação para uma performance de rua. Tantas referências, tantos debates sobre a presença de corpos dissidentes nas ruas, tantos protocolos de trabalho, tantas investigações em ruas e praças. Tanta empolgação... E aquela ligação acontece. Diante de tamanha violência nada parecia fazer sentido. Qualidade de movimento? Dramaturgia? Estruturas de mediação com o ambiente público? Conceitos? Tudo que ontem parecia um conjunto incrível de propostas, hoje parecem alegorias de faz de conta. Como pensar em arte diante da importância de olhar para demandas tão básicas de sobrevivência?

Foram muitos dias sem conseguir colocar nada em movimento. E quando consegui voltar minimamente ao trabalho, um peso, um choro, um corpo que não sai do chão. E é aí que lembro nitidamente dos dilúvios de um 
corpo que se infiltra-esparrama no chão gelado. E eu estava lá, naquele chão, para ensaiar. Para criar. E foi na angústia de viver a impossibilidade de mover que a estrutura performática de "Não alimente os animais" se construiu.

I. (para criar vivendo dentro do olho do furacão da barbárie)

Estar criando em arte é desafiar-se a inventar outro mundo. Outros mundos. É um exercício de procurar espaço e tempo para poder destruir o espaço e o tempo. É aventura de produzir ficções outras em meio às ficções que chamamos, na vida cotidiana, de realidade. E faz tempo que criar, para $\mathrm{mim}$, tem sido gradativamente desistir de ser humana. De certo modo, acredito que a humanidade é um projeto que fracassou, e que novos projetos de existência estão por aí, vivos, disponíveis, em curso. Não é pessimismo, nem fatalismo. Pelo contrário: é potência de desejo, é apostar que podemos mais, podemos outra coisa. Pensando assim, criar é sempre morrer um pouco. Morrer, matar, mover.

$E$ tais dimensões, quase que paradoxalmente, parecem se tornar mais evidentes no encontro. No encontro com outros corpos, outras intimidades. Chamo essa bruxariazinha de "poética do encontro". É sobre olhar com cuidado para o tamanho enorme da potência do encontro entre corposexistências. Ao valorizar o corpo novo que passa a existir quando entro e deixo o outro entrar, admito e compreendo o encontro como método de pesquisa. Não qualquer tipo de encontro, mas um encontro que se pretende revelador $e$ cúmplice.

Performativamente, pensar o encontro como poética significa estabelecer e pactuar outras formas de olhar para a vida que se estabelece na relação com o outro, procurando nessa relação nossa matéria poética. Mas não qualquer tipo de encontro. Quero encontrar com as monstras e criar situações para que elas se encontrem entre si, para poderem juntas olhar para os avessos dos corpos e experimentar possibilidades de coletivizá-los, para quem sabe viver um corpo bizarro-ciborgue colaborativo. Para no encontro 
potencializar estranhezas. Todo corpo é monstro, toda fisicalidade tem seu perfume bizarro. Quero tocar e amplificar as estranhezas que vivem em cada corpo, tornar visíveis corporalmente todas aquelas esquisitices que ao longo da vida aprendemos a esconder. Onde as experiências de monstros se cruzam? E onde se distanciam? Como atualizar juntas nossas formas de perceber-viver um mundo cada vez mais organizado para nos deslegitimar, respondendo esteticamente a ele?

$\mathrm{Na}$ vida e na arte dedico tempo e atenção para as estranhezas e particularidades que fazem de mim, de nós, os corpos que somos. Olhar para os avessos dos corpos e experimentar possibilidades de coletivizá-los, para quem sabe viver um corpo bizarro-ciborgue colaborativo. Todo corpo é monstro, toda fisicalidade tem uma tendência ao bizarro. Quero tocar e amplificar as estranhezas que vivem em cada corpo, tornar visíveis corporalmente todas aquelas esquisitices que ao longo da vida aprendemos a esconder.

O Manifesto Ciborgue, de Donna Haraway, originalmente publicado em 1985, é um convite explícito a superar nossa noção cristalizada de humanidade. A gata é radical: não há um corpo natural. Ela constrói a imagem de um ciborgue como um híbrido de máquina e organismo, uma criatura de realidade social e também de ficção. Corpos máquinas. Não no sentido mecanicista moderno, mas numa atitude sistêmica, complexa e antinaturalizada de existência. "(...) somos todos quimeras, híbridos - teóricos e fabricados - de máquina e organismo; somos, em suma, ciborgues".1

O ciborgue é uma criatura de um mundo pós-gênero. Ele não tem compromisso com a bissexualidade, não tem fascínio por totalidade orgânica, não faz apelo a uma narrativa de origem. A imagem do ciborgue pode sugerir uma forma de saída do labirinto dos dualismos por meio dos quais nossos corpos são explicados. O ciborgue, nessa perspectiva, aponta para além de qualquer binarismo, seja este homem-mulher ou ser humano-máquina. $\mathrm{O}$ ciborgue é um monstro e os monstros definem os limites de nossa identidade, questionam os fundamentos do discurso sobre o natural $\mathrm{x}$ sobrenatural. Para

\footnotetext{
1 HARAWAY, Donna. Manifesto Ciborgue. In: TADEU, T. (Org.). Antropologia do ciborgue: as vertigens do pós-humano. 2. ed. Belo Horizonte: Autêntica Editora, 2009.
} 
Haraway (e eu estou junto com ela nessa), já vivemos um mundo pós-humano e pós-gênero em diversas dimensões.

O ciborgue de Haraway, assim como a abjeção Butleriana2, podem ser marcadas pela incompreensibilidade de determinadas experiências a partir da lógica cultural hegemônica, sendo tratadas de maneira animal, bestificada. Assim, o que inicialmente parece ser um problema do indivíduo "degenerado" que se encontra afora ou à margem da sociedade, torna-se um problema da sociedade que em seus registros limitados e limitantes não consegue compreender a experiência daqueles que mesmo tendo sido produzidos em seu seio, Ihe são alheios ou aparentemente externos.

Abjeto é aquilo que precisa ser constantemente repudiado em si para se ascender ao status de sujeito, uma vez que os corpos jamais se materializam completamente, pois há em cada corpo algo de abjeto. Algo que precisa ser constantemente negado, alijado, para que ele seja incluído no rol dos sujeitos.3 A abjeção existe e sua existência que incomoda e torna a lei confusa. As contradições e complexidades do corpo abjeto, que só pode ser visto como não-sujeito num mundo de linguagem e, portanto, de sujeitos, na minha visão precisam ser entendidas como trunfo ontológico e não como problema a ser combatido. Especialmente na prática artística.

Em 2008, depois de assistir a "Não alimente os animais", Marcio Marciano (crítico de teatro) me procurou para parabenizar pelo trabalho. Entre as afirmações uma me marcou muito. "Aprendi com Lenin que o movimento vem da margem", disse ele. Depois fez uma analogia dialética fazendo alusão aos círculos concêntricos que a pedra produz na água quando arremessada. No caso de Lenin, a ironia está em reconhecer como é frágil a ilusão de nos sentirmos no centro e, a partir daí, tentarmos promover transformações, sem atentar que essas transformações nunca partem de um lugar unívoco, mas se condicionam mutuamente num processo de contínua negação.

Quando você não importa, está vulnerável a todo tipo de desmando, injustiça e desumanidade. As regras de convivência entre humanos não

\footnotetext{
${ }^{2}$ BUTLER, Judith. Problemas de gênero: feminismo e subversão da identidade. Tradução de Renato Aguiar. Rio de Janeiro: Editora Civilização Brasileira, 2003.

${ }^{3}$ BUTLER, Judith. Undoing Gender. New York-London: Routledge, 2004.
} 
servem para aquilo que não considero classificável como humano inteligível. O agressor que joga um balde de ácido em uma travesti trabalhando na rua durante a noite o faz pois não enxerga naquele ser vivo um semelhante. $E$ talvez não seja mesmo um semelhante. E talvez nosso pulo do gato na loteria dos sujeitos seja exatamente desistir da querela por sermos tratadas como "mais sujeitos". Talvez os processos citacionais que constituem o corpo das monstras, prestes a serem queimadas por um balde de ácido nas mãos de um homem branco conservador, constituam mesmo um resultado que está fora. E quero entender que é dali, de fora, que pode vir movimento. Um outro movimento.

No Brasil, durante a greve dos caminhoneiros em junho de 2018, um vídeo onde uma travesti moradora de rua é entrevistada, viralizou nas redes. 4 Trata-se de Adriana Cavalcanti, de 29 anos, que vive há 17 nas ruas de Campinas (SP). Na entrevista, assim como em outros vídeos que podem ser encontrados na rede, Adriana demonstra articulação e erudição muito além do que o mundo espera para a sua condição. Entre outras coisas ela fala de sua paixão pelos livros, dizendo que eles foram a solução para sua condição de solidão. "Na falta de com quem conversar, eu entendi que os livros falam. Eles estão sempre a falar", diz.

Entre passagens bastante emocionantes e outras bem engraçadas, 0 que mais me chamou a atenção foi a percepção que ela tem de sua posição de outsider. Começando seus comentários sobre a greve, afirma que "está de fora, e de fora é mais fácil para enxergar".

Parece que está na hora de responder, resistir a partir de outros parâmetros.

Das coreopolíticas propostas por André Lepecki, às zonas autônomas temporárias provocadas por Hackim Bey, passando pelo manifesto ciborgue de Donna Haraway ou pela contrassexualidade proposta por Paul Preciado: onde, como e por quais motivos resistimos? Respondemos? Contraatacamos? Quantos lados tem essa guerra? Como cada um destes artistas

\footnotetext{
${ }^{4}$ Disponível em: https://g1.globo.com/sp/campinas-regiao/noticia/apaixonada-por-literaturamoradora-de-rua-transexual-viraliza-na-web-na-solidao-comecei-a-conversar-com-os-livros.ghtml (consultado em 20/07/2018).
} 
descreveria suas estratégias pessoais para lidar com os golpes em curso? Onde suas experiências se cruzam? E onde se distanciam? Como atualizar juntas nossas formas de perceber e responder aos ataques violentos cada vez mais presentes? Mais que apresentar uma receita, como reaprendemos a compartilhar algumas perguntas, estratégias, dilacerações e inspirações?

$\mathrm{O}$ que eu quero é tocar fogo no gênero. Na identidade. Na caixinha na qual nunca coubemos. Nos atrevemos a pensar em uma sociedade pósgênero, em uma forma de compartilhamento da existência menos categorizadora. E em tempos tão sombrios, violentos e de um fortalecimento voraz de atitudes conservadoras, a arte precisa redobrar os esforços de uma crítica radical aos modelos naturalizantes e naturalizados.

II.

\section{(corpos desobedientes de gênero performando na/a cidade)}

Em geral, temos o entendimento de que a arte é a priori - ou pelo menos deveria ser - pública. No entanto este entendimento não me é suficiente e no desejo de produzir experiências efetivamente relacionais, faz tempo que mergulho no caótico, complexo, violento e sedutor lugar onde partilhamos a existência com as nossas: ruas, praças, calçadas. Principalmente calçadas.

Em "Não alimente os animais" a calçada surge não como uma escolha arbitrária, mas sim como uma necessidade vital do projeto. Só nela a discussão que estamos propondo teria condições de ser desenvolvida.

Olhando para o espaço público como o da negociação coletiva, do "estar/conviver juntos", saímos em busca de encontrar as formas mais intensas e desafiadoras de contribuir para uma convivência outra, para um outro pacto de partilha. Nicolas Bourriaud fala de um "estado de encontro imposto aos homens". Criar na rua seria, então, procurar brechas nesse encontro imposto em busca de torná-lo mais ativo e menos imposto, mais escolhido e negociado, e menos massificado. 
Estive e estou interessadx numa ação imediata, pontual, reconhecível e acessível a um público espontâneo. O corpo em ação ressignificando um espaço-tempo real (real?), despertando a atenção para ele e oferecendo outras formas de observá-lo e de perceber o contexto a sua volta, mais críticas e criativas, produzindo recepções e reverberações imediatas e diretas da obra, transitando no limiar entre o estabelecido e o provisório, entre a institucionalização e o espaço público, entre a repetição e a diferença.

Então, era 2010, o corpo-dilúvio-revolta infiltrado no chão gelado começou a rastejar. Se o peso-mundo é inevitável agora, como é que inventopolitizo mundos daqui, do chão. E a insistência no movimento de um corpo dilacerado vai dando forma a um monstro que ao arrastar o corpo na calçada abre uma fenda nas relações cotidianas.

Pouco a pouco vi meus desejos subversivos, desobedientes, e quase terroristas passarem do campo da tristeza para o ataque, um ataque que é também um convite. Convite para uma experiência sensível, um evento capaz de gerar uma fissura neste espaço/tempo, interrompendo seu continuum, reconfigurando tanto o contexto quanto os corpos que agem dentro dele.

III.

\section{(trajetória de fendas em calçadas)}

A arte inquieta de Princesa Ricardo Marinelli renuncia a propaganda publicitária para ir ao encontro desnudar cumplicidades.

Age para tomar de assalto os desavisados, e então espelhar a selvageria camuflada e a violência explicitada na intolerância.

Evidencia na carne que os preconceitos continuam as maiores barreiras para a produção do conhecimento.

A burrice perdeu de vista e o chorume é humano.

O banho lava o cheiro das ruas mas não tira a purpurina da cara.

O salto quebrou. A meia arrastão está rasgada.

A escultura continua, ampliada. E o pensamento escapou da prisão...

(Kleber DAMASO, sobre "Não alimente os animais", para o Caderno Corpo Exposto, 2012) 


\section{Figura 1: Curitiba, 2012.}

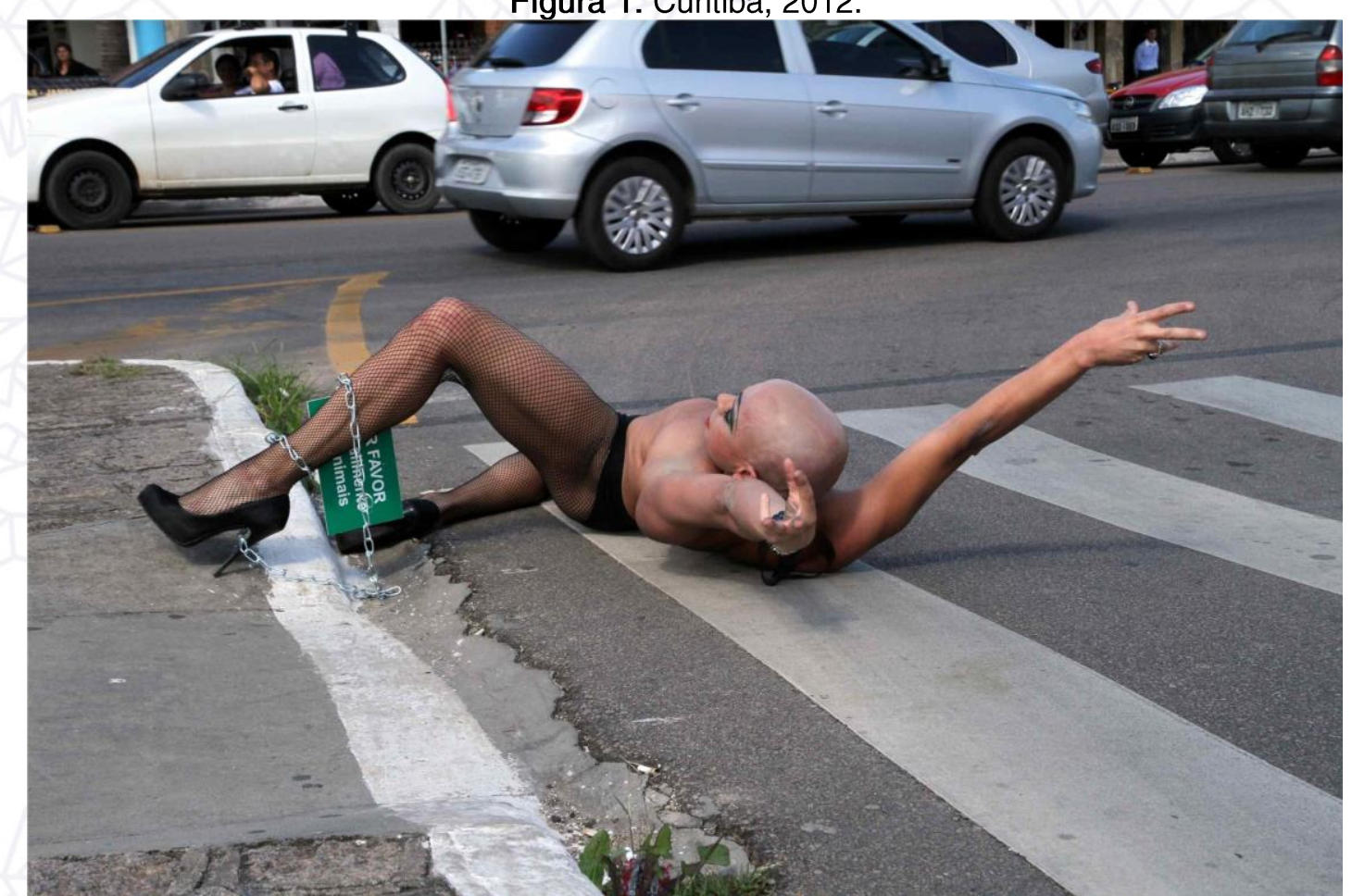

Foto de Leco de Souza.

"Não alimente os animais" é, então, uma ação performática que procura tornar vivíveis corpos que têm sido escamoteados, escondidos e marginalizados. Princesa é um corpo bizarro de rua, que atua durante o dia. Ela evidencia o tratamento zoológico que é dado aos corpos desobedientes de gênero, em especial travestis e/ou transexuais. O chão, a calçada, a rua, a beleza, a violência, a venda. Tudo converge para um corpo que não anda, mas rasteja. 
Figura 2: São Luís do Maranhão, 2013.

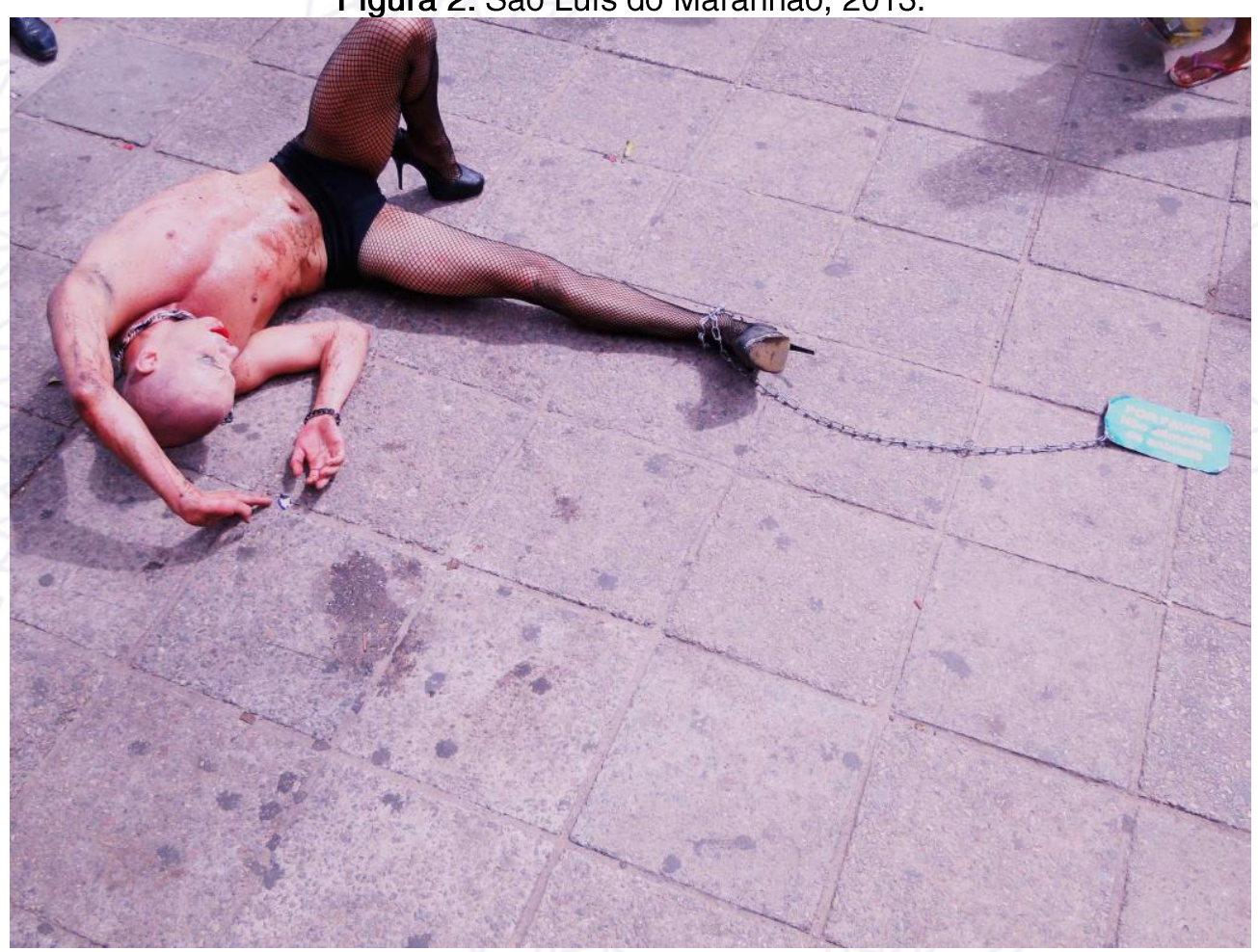

Foto de Taciano Brito.

Figura 3: São Luís do Maranhão, 2013.

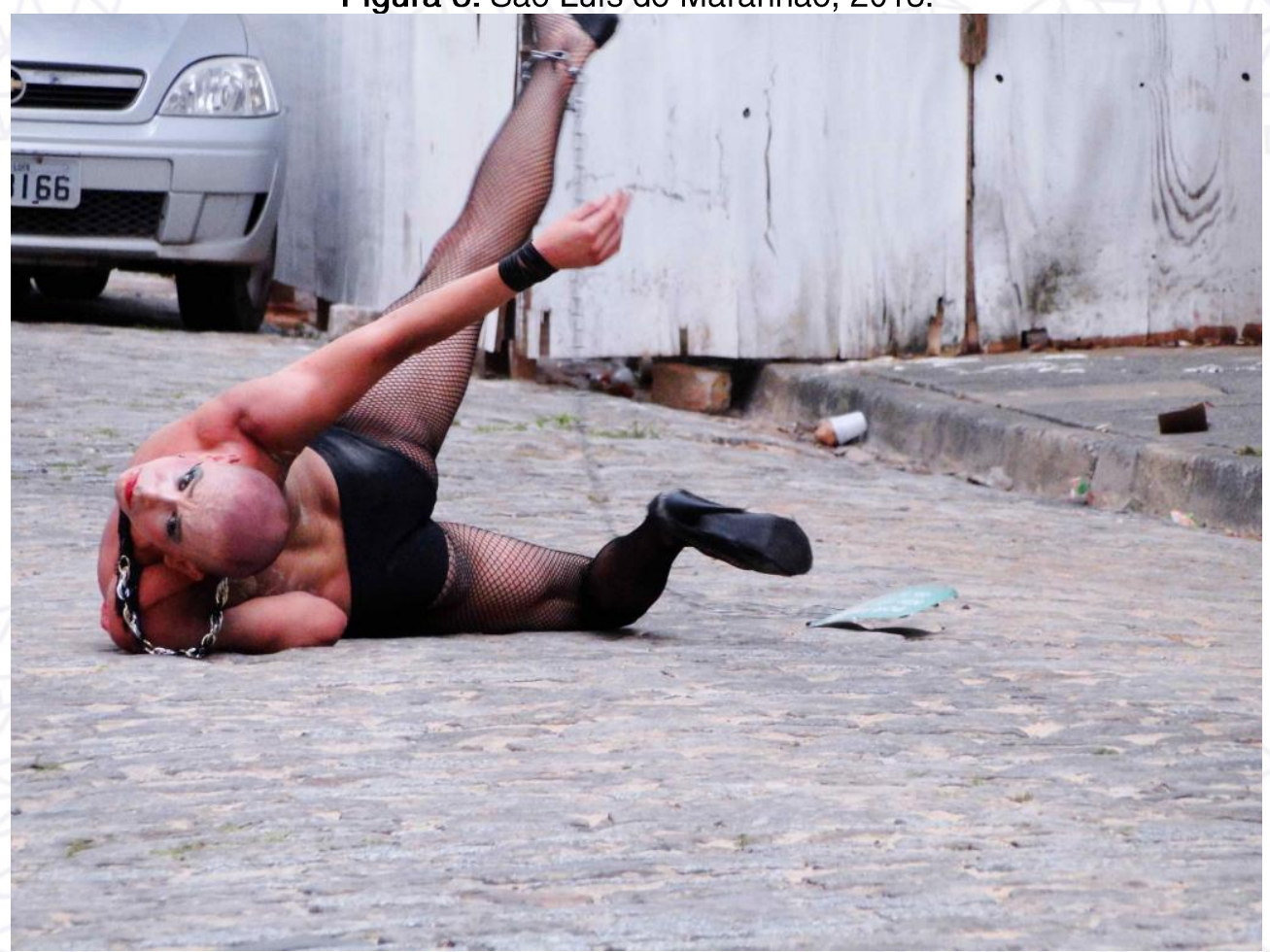

Foto de Taciano Brito. 
Vestindo apenas uma calcinha, meia arrastão, saltos enormes, maquiagem detalhada e muitos colares, o corpo de Princesa rasteja, durante o dia, por calçadas com grande circulação de pessoas. Calçadas onde mais tarde, quando a noite e o escuro chegam, travestis colocam seus corpos à venda. Além de seus longos cílios, purpurina e batom vermelho, Princesa carrega uma corrente amarrada em seu tornozelo. Na ponta da corrente uma placa verde, com a inscrição: "POR FAVOR Não alimente os animais". A beleza glamourosa se movimenta pelo chão, rastejando e rolando pela sarjeta durante pelo menos 15 quarteirões. A ação dura por volta de 45 minutos.

A síntese performática é minha resposta possível às inquietações daquele corpo que esteve paralisado naquele chão gelado desaguando. Uma resposta em relação às possibilidades de presença de corpos desobedientes de gênero e sexualidade nas ruas, especialmente aqueles que experienciam a transgeneridade. Corpos fortes, potentes, repletos de autoafirmação, mas que vivem a restrição de uma existência abjetada, uma existência na margem. A síntese física na obra aponta para essa ambiguidade existencial (força $x$ abjeção): é a construção de um corpo e de uma movimentação muito precisa, virtuosa, articulada e flexível, mas que só rasteja. Um corpo cheio de virtudes, mas que independentemente do que faça continuará abaixo, muito abaixo e na sarjeta. Pois então, Princesa entendeu que a fricção e a ambiguidade estão exatamente no fato desse corpo ocupar o espaço público durante os momentos em que a princípio não são permitidos: a luz do dia e do conservadorismo do horário comercial. 
Figura 4: São Luís do Maranhão, 2013.

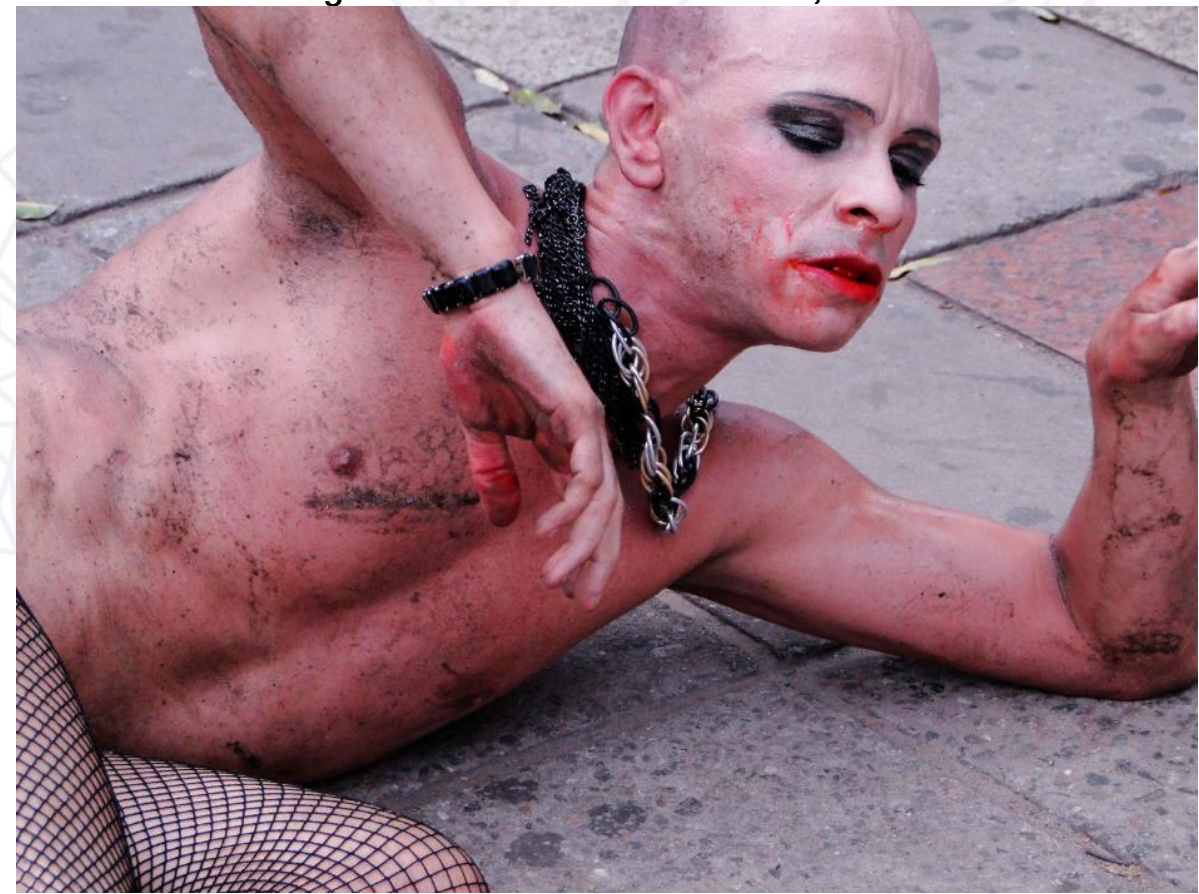

Foto de Taciano Brito.

O título é uma ironia, uma apropriação que tem a intenção de provocar os discursos e defesas dos conservadores. Não faltam, em nossas sociedades, projetos higienistas e eugênicos. Através de diversos tipos de investimentos, o corpo é esquadrinhado, medido, julgado e a partir daí colocado na sua devida gaveta. Fora do domínio da normalidade (e esse entendimento de que estão "fora" é uma ilusão do discurso conservador que usamos a nosso favor), estamos nós. Sujeitos que estão experimentando um outro status de existência, que afirmam suas esquisitices não como defeito, mas como qualidade inerente e potência transformadora. O discurso médico, jornalístico e cristão conservador diz que somos bizarras. Se ser bizarra é questionar a necessidade de adequar nossa forma de existir a um modelo de interesse branco- ocidental-cristão-machista-heterosexual, sim, somos bizarras e agora reivindicamos nosso direito a ser assim. $O$ tom pejorativo e violento da utilização inicial da expressão ganha outra roupagem quando o movimento social se apropria dela. Uma inversão de valores irônica que tem grande chance de provocar fortes ruídos na fortaleza conservadora, já que depois de classificar alguns corpos como bizarros, a tendência tem sido tratá- 
los de uma forma que tenho descrito como zoológica. Corpos que são desumanizados e abordados sob a lógica do safári exotizante.

Desde a primeira aparição oficial da performance, no 20minutos.MOV (Curitiba, outubro de 2010), já pude passar com "Não alimente os animais" por algumas e muito diferentes cidades do país, o que complexificou e potencializou a força do acontecimento proposto, que a cada novo contexto parece se fortalecer. As recepções e reações tem sido de diversas naturezas (diversas mesmo), mas aqui seleciono algumas recorrências e também alguns fatos que merecem destaque, tudo na tentativa de defender a importância da continuidade desse projeto e, portanto, que ela possa visitar novos contextos.

Figura 5: São Luís do Maranhão, 2013.

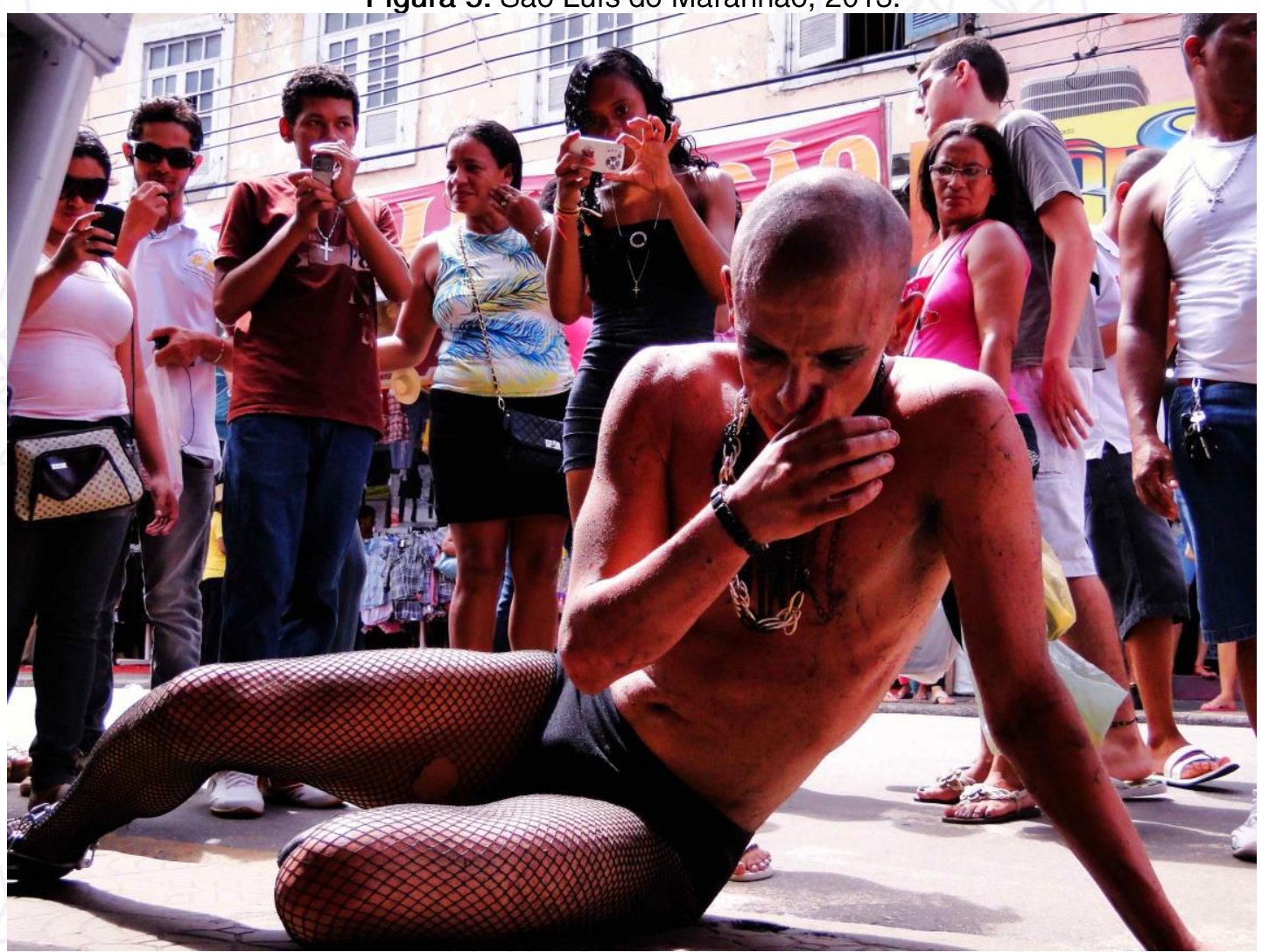

Foto de Taciano Brito.

Uma dimensão que persigo já faz tempo em minhas performances que acontecem na rua, é a proposta de ter uma ação que não seja tão rapidamente explicada como "dança", ou como "arte". Me interessa manter a dúvida, a ambiguidade. E no projeto "Não alimente os animais" isso acontece com muita força. 
Existem aqueles que acreditam ser mesmo uma pessoa que não pode caminhar, aqueles que tem certeza que é uma travesti que levou uma surra na rua de cima, que é um louco que estava acorrentado em algum canto e fugiu. Fala-se também que se trata de um manifesto em defesa dos animais da Amazônia. Mas o que mais me deixa satisfeito são aquelas pessoas que permanecem na dúvida e se inquietam com ela.

Em uma das apresentações, em Manaus, que juntou muitos adolescentes que haviam acabado de sair de sua escola e me acompanharam durante todo o percurso, um garoto me acompanhou lado a lado por três quarteirões, pedindo desesperadamente por uma explicação. "Por favoooooor, me diz o que é isso que você tá fazendooooo", dizia ele.

Muitas são as reações violentas. Muitas agressões verbais, muita gente desviando o caminho com nojo ou desdém, mas houve também aquelas reações ampla e declaradamente violentas. Em Irati (uma pequena cidade do interior do Paraná), ao atravessar uma praça, fui interpelado por um homem que esperou o momento certo durante meus movimentos, para cuspir na minha cara. Um cuspe tão grande que tive que tirar a gosma dos olhos com as mãos para poder continuar meu caminho. Em outra ocasião, em Fortaleza, um homem se sentiu no direito de enrolar uma pedra enorme (devia pesar mais de meio quilo) em uma camiseta e arremessá-la contra as minhas costas.

Por outro lado, em outra cidade do Paraná (Toledo) uma senhora de aproximadamente 80 anos, me acompanhou silenciosamente por todo o percurso, olhando atentamente para todos os lados, assumindo a função de segurança da situação. 
Figura 6: São Luís do Maranhão, 2013.

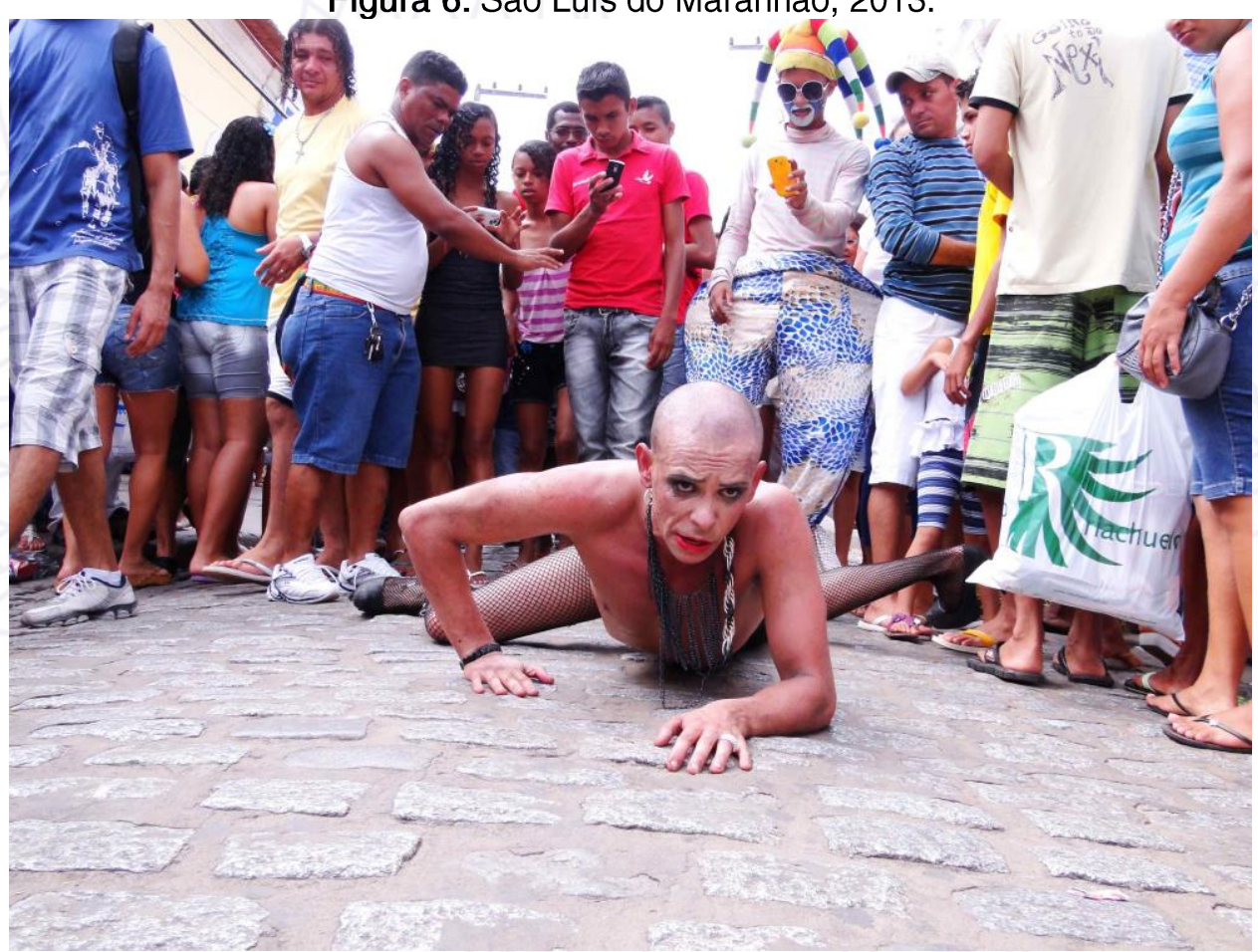

Foto de Taciano Brito.

Figura 7: São Luís do Maranhão, 2013.

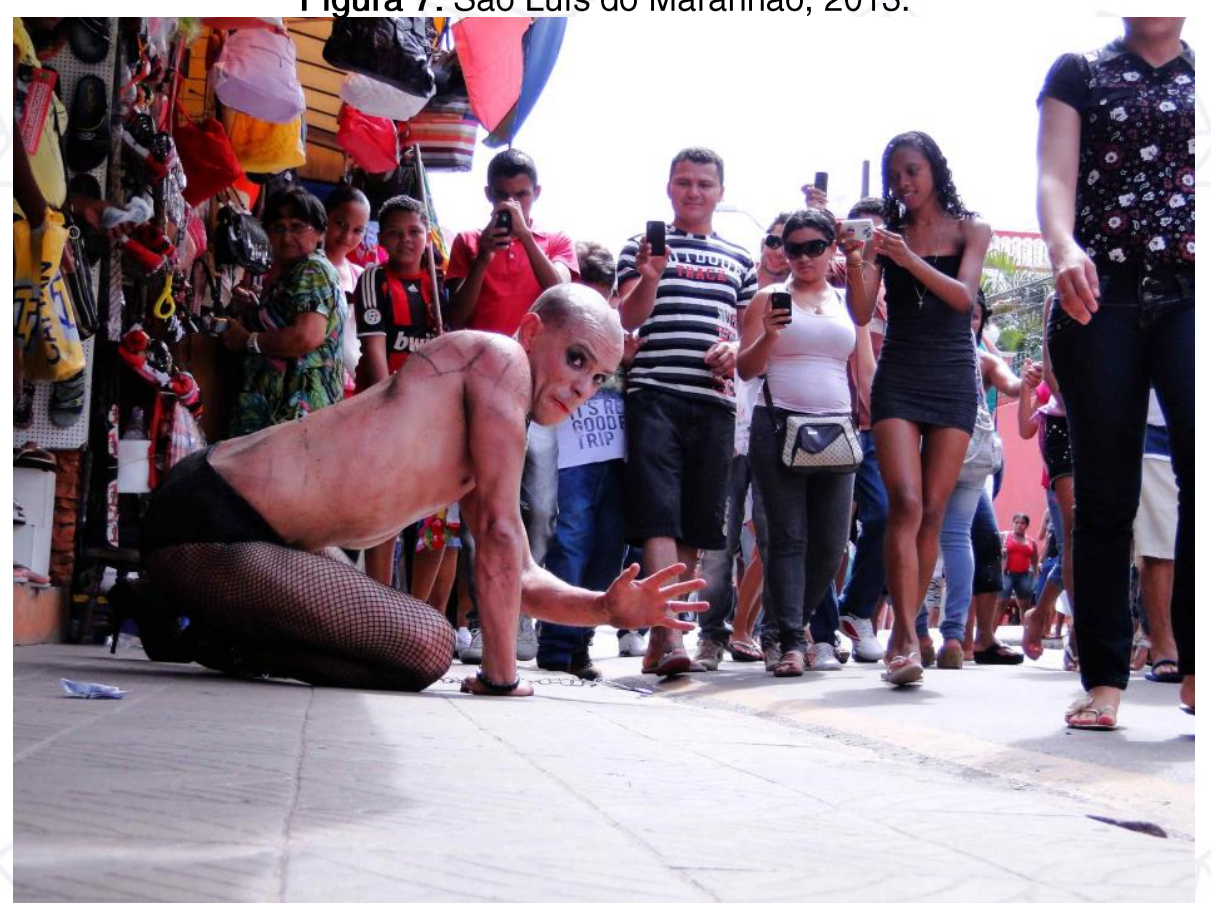

Foto de Taciano Brito.

Uma situação recorrente que vale destacar, diz respeito à noção de permitido / não permitido na vivência do espaço público. Nessa performance não existe nenhum crime sendo cometido, nenhuma infração penal, nada que 
possa ser legalmente julgado. Eu tomei o cuidado de investigar isso. No entanto, em cada 10 vezes que apresento a performance, em 7 a polícia é acionada e intervém. Às vezes com mais violência, às vezes nem tanto, mas ela sempre está lá, na tentativa de parar a ação.

Figura 8: Curitiba, 2012.

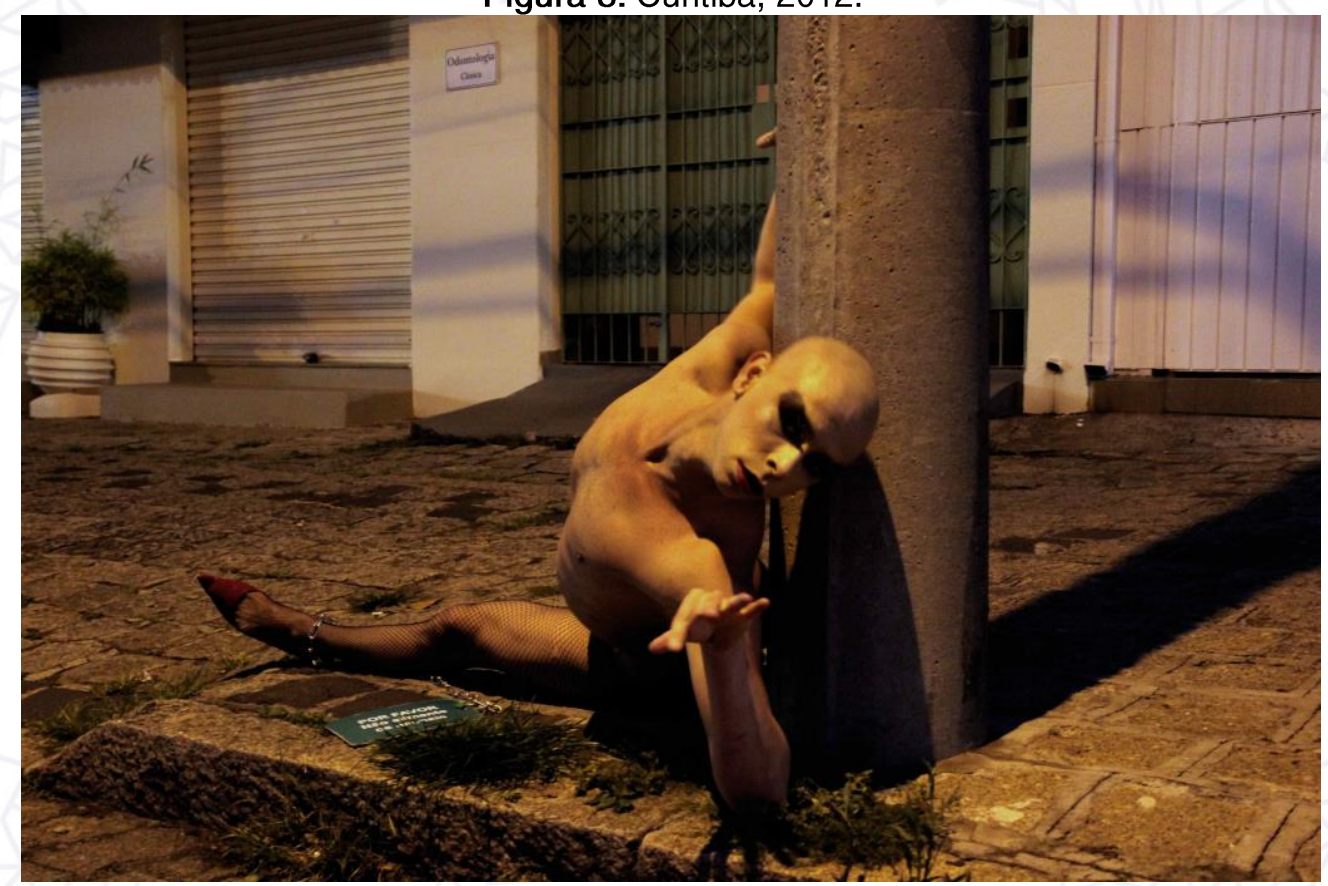

Foto de Leco de Souza.

Figura 9: Curitiba, 2012.

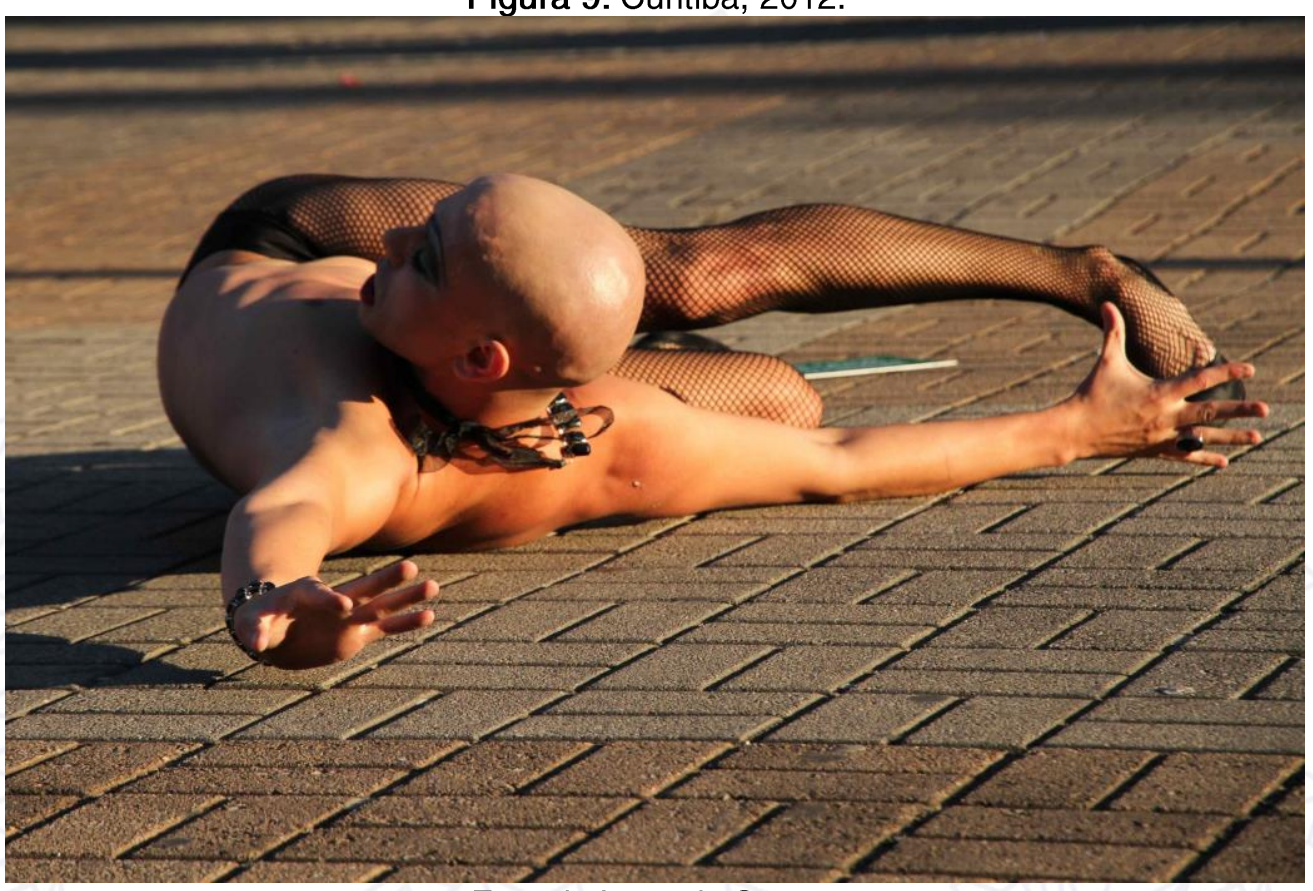

Foto de Leco de Souza. 
Em Manaus, numa rua perto da Praça da Saudade, fui abordado por quatro policiais. Enquanto dois bloqueavam meu caminho, um pisava com muita força na minha corrente e o quarto me intimidava, olhando nos meus olhos e dizendo que se eu não levantasse, ele teria que me levar com ele para a delegacia. Ora essa. Dez metros à nossa frente havia uma moradora de rua deitada sobre seus papelões, mas o fato de eu tomar a decisão de rastejar espontaneamente e ter condições de defender meu direito de fazê-lo, são demasiadamente violentos para o policial. Só depois que a organização do evento interviu (agindo expressamente contra a minha vontade) declarando aos policiais que se tratava de uma "performance" e que "já estava acabando", me deixaram continuar o caminho.

Das intervenções policiais sempre fico com algumas perguntas: quando ele tenta parar a ação, o faz para defender quem do quê? O faz em nome de que força de lei? Ou em nome da manutenção de algo? Quase sempre fico com a impressão de que eles não sabem mais o que precisam realmente proteger, muito menos de quê.

E finalmente aponto outra recorrência nas reações das pessoas, algo que acontece em praticamente $100 \%$ das vezes que mostro o trabalho: a intervenção de cunho religioso, na maioria das vezes de evangélicos fervorosos. Em São Luís do Maranhão, rastejando pelas ruas ao redor da Praça Deodoro, acabei passando ao lado de um grupo de adolescentes evangélicos que ali estavam para pregar. Rapidamente, um grupo de 5 meninas me cercaram, levantaram suas mãos sobre mim e aos gritos de "demônio, sai desse corpo que não te pertence!". Foram minutos de uma espécie de exorcismo. Uma situação violenta e preconceituosa, que ficou ainda mais difícil quando elas tentaram me tirar do chão à força, alegando que "Jesus já havia me ungido com seu poder". Situações desse tipo voltaram a ocorrer em diversos contextos, mas em Goiânia apareceram de uma forma inusitada: nas duas vezes que realizei por lá a performance, um pastor (diferente para cada vez) se aproveitou da minha ação e do público que se acumulou para ela para pregar, me usando como exemplo da "manifestação do diabo". Todos esses acontecimentos me fazem diagnosticar uma questão 
que muito me interessa: existem muitas formas de reações, mas raramente alguém passa ileso. A performance exige de quem a vê, um posicionamento.

Figura 10: Rio de Janeiro, 2014.

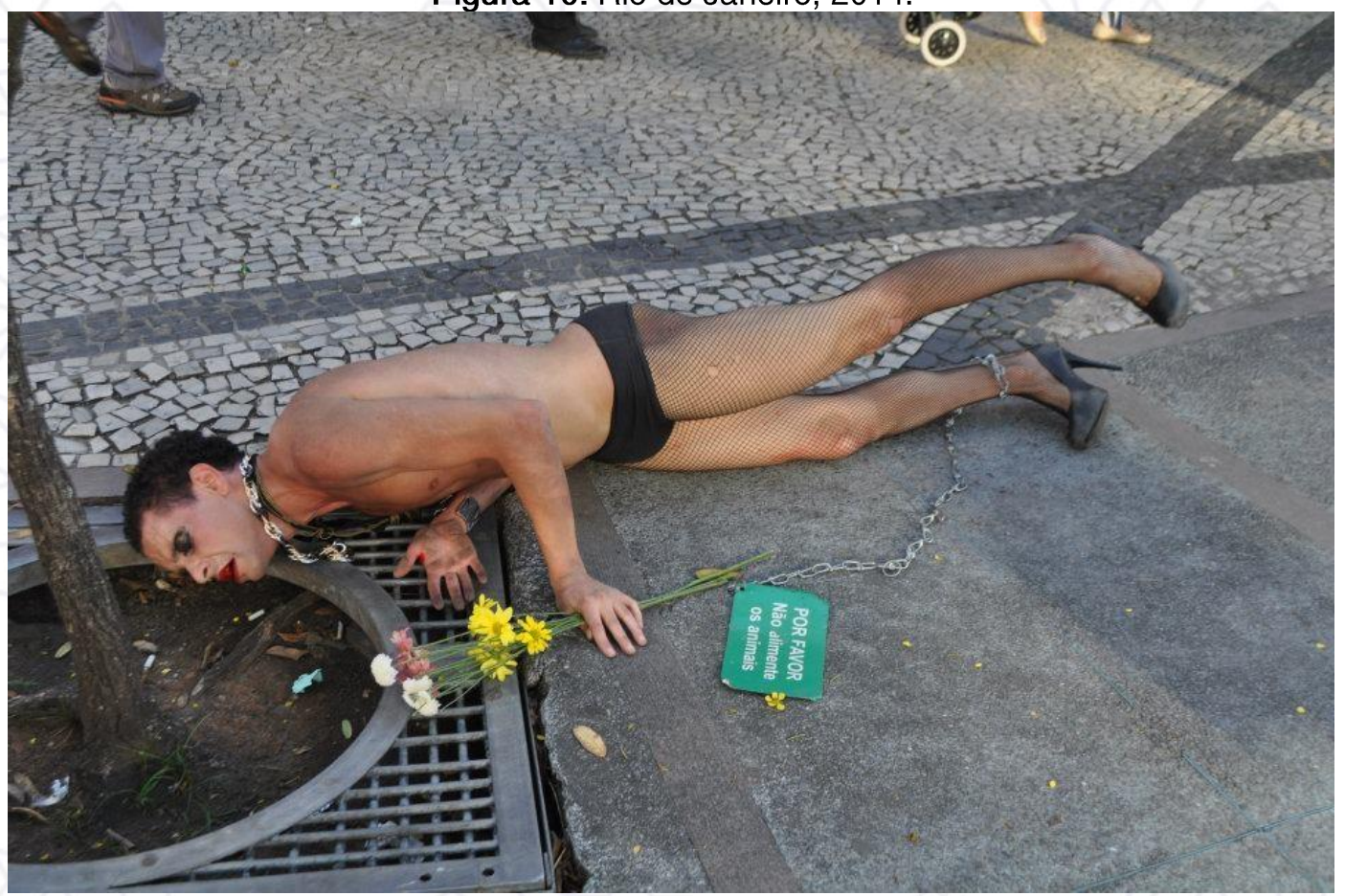

Foto de Nayse Lopez.

Figura 11: Rio de Janeiro, 2014.

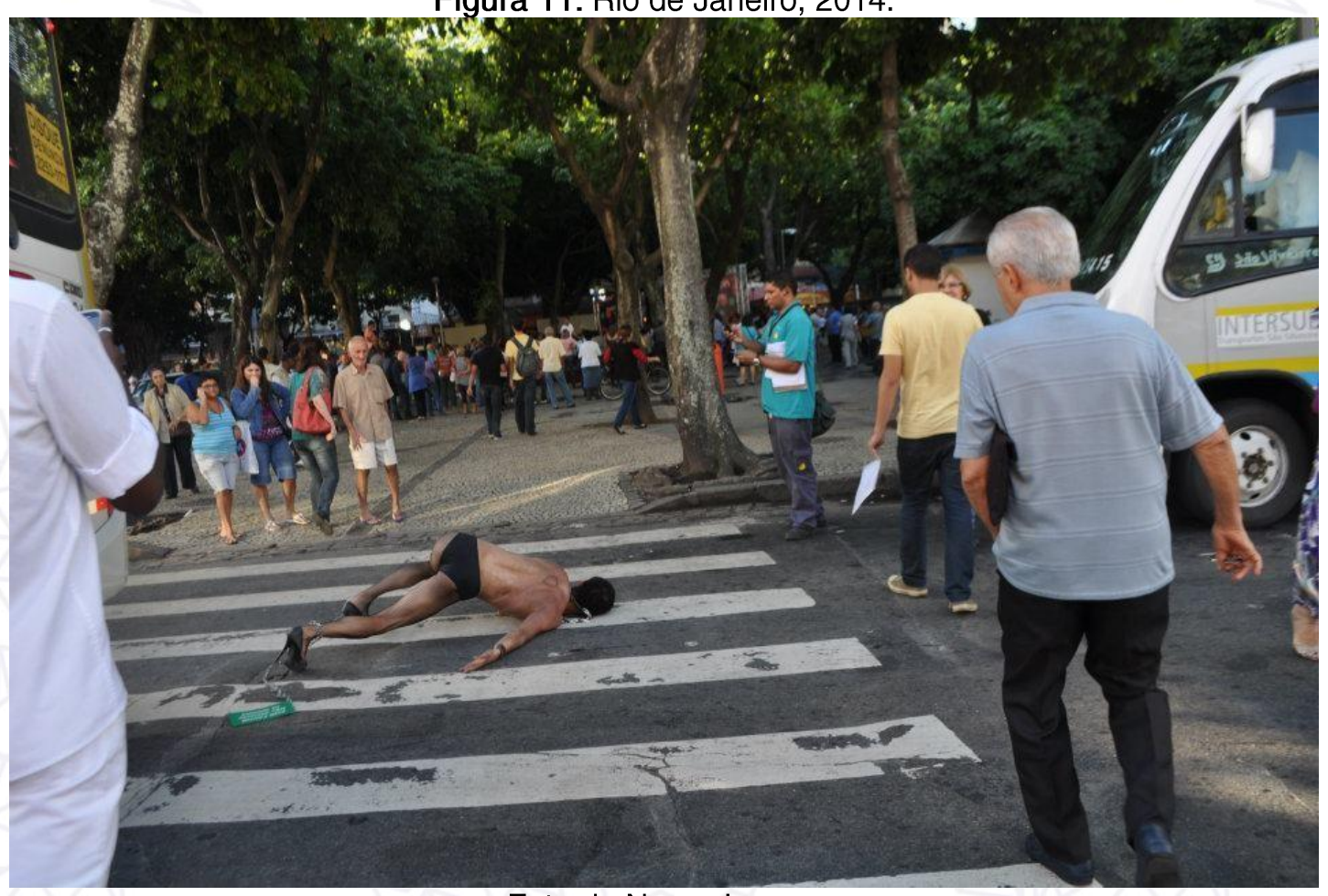

Foto de Nayse Lopez. 
"Não alimente os animais" é uma ação performática que tem como foco um corpo tratado zoologicamente, exotizado, coisificado, animalizado. Um corpo que tem sido tratado como menos humano que os outros. "Não alimente os animais" é uma das respostas artísticas que tenho dado a esse diagnóstico e ao medo que tenho de perder uma amiga a cada dia. ${ }^{5}$

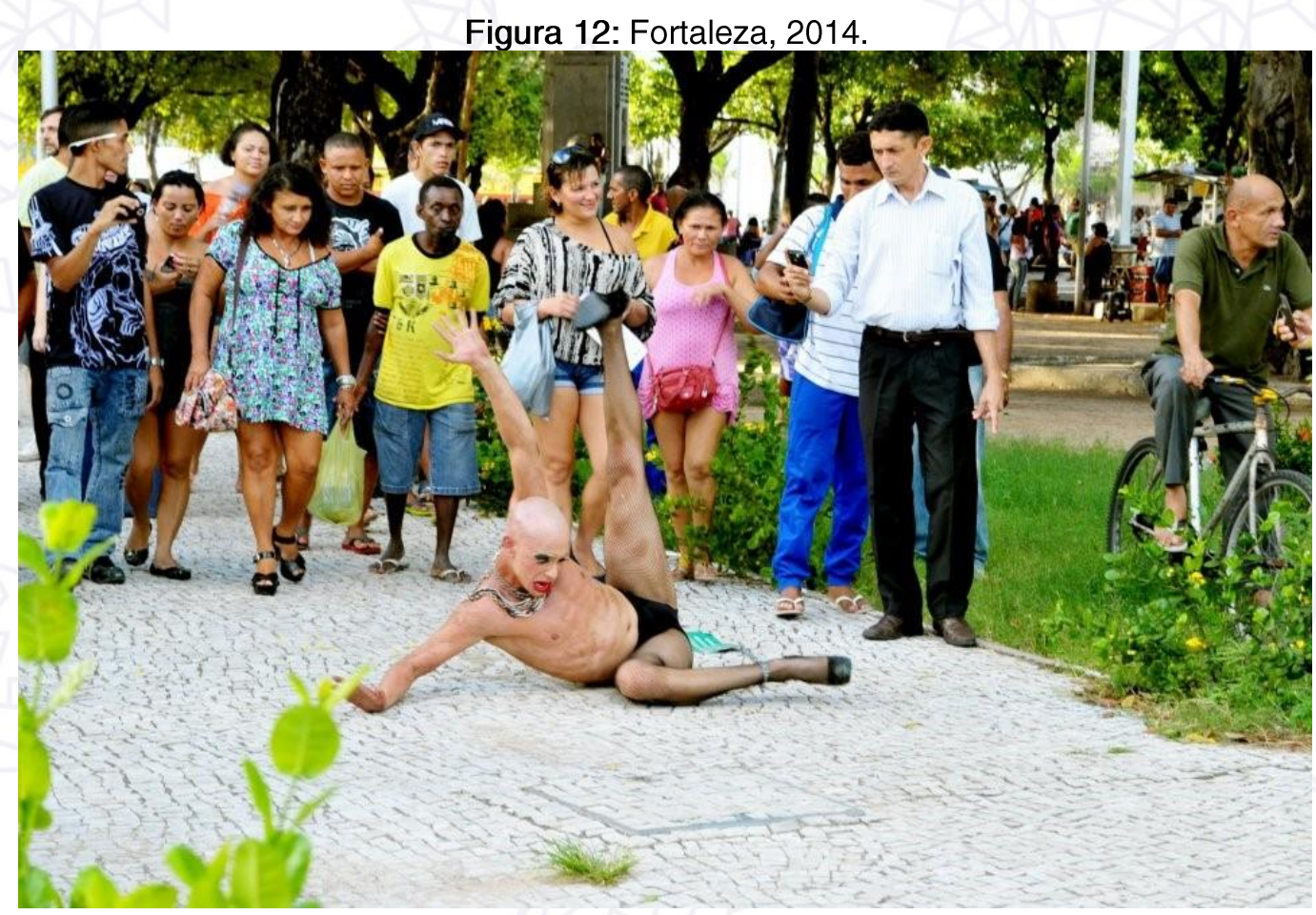

Foto de Marcelo Alasino.

5 Vídeo da performance, captado e editado em 2012 por Leco de Souza:

https://vimeo.com/31148968; Registro de processo, captado e editado em 2011, por Alessandra Haro: https://www.youtube.com/watch?v=AfLs3DOWUlk; Vídeo da performance, captado e editado na edição 2018 do DIGO - Festival Internancional da Diversidade Sexual e de Gênero de Goiás: https://www.youtube.com/watch?v=joNSGvlg8pw; 
Figura 13: São Luís do Maranhão, 2013.

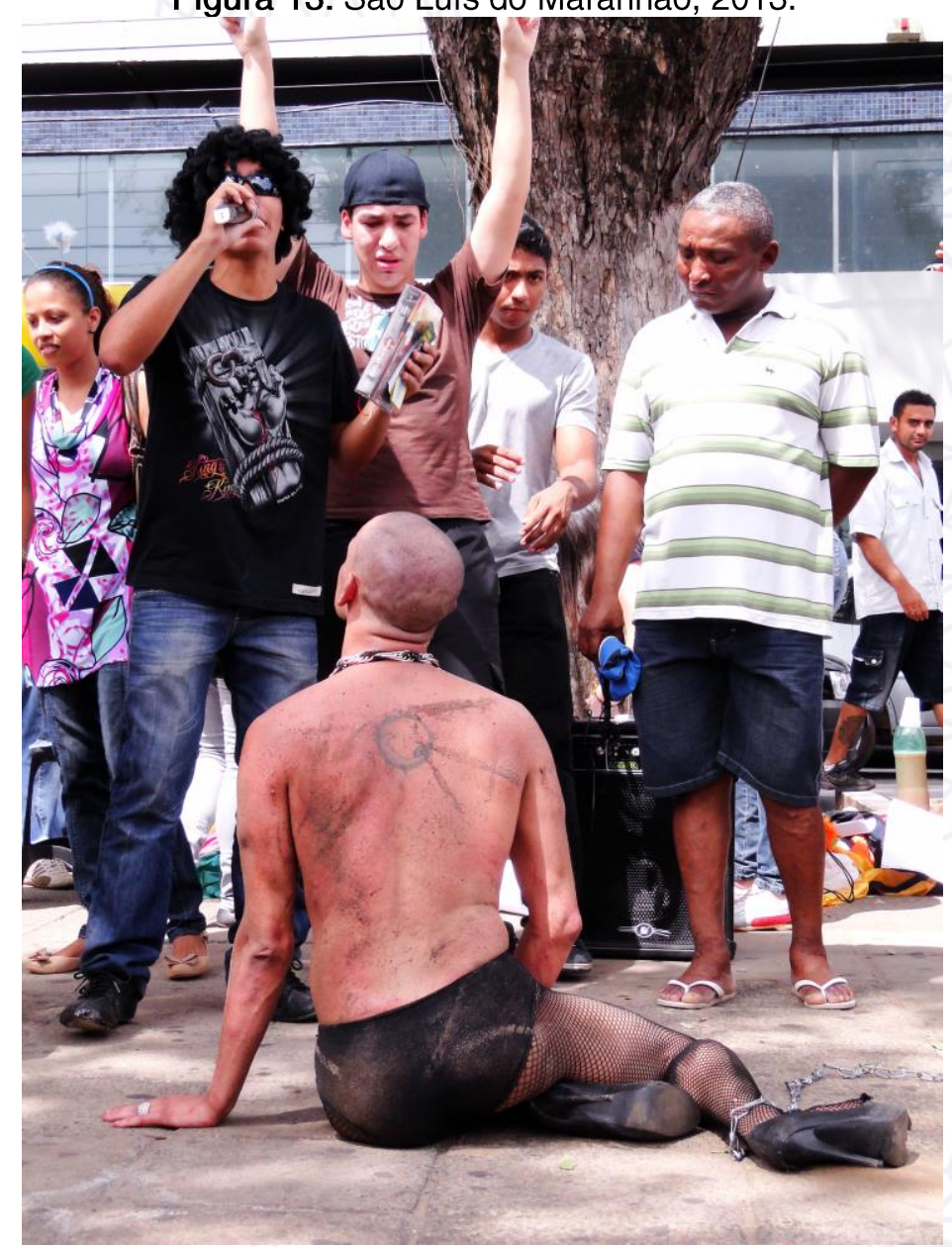

Foto de Taciano Brito.

Figura 14: Fortaleza, 2014.

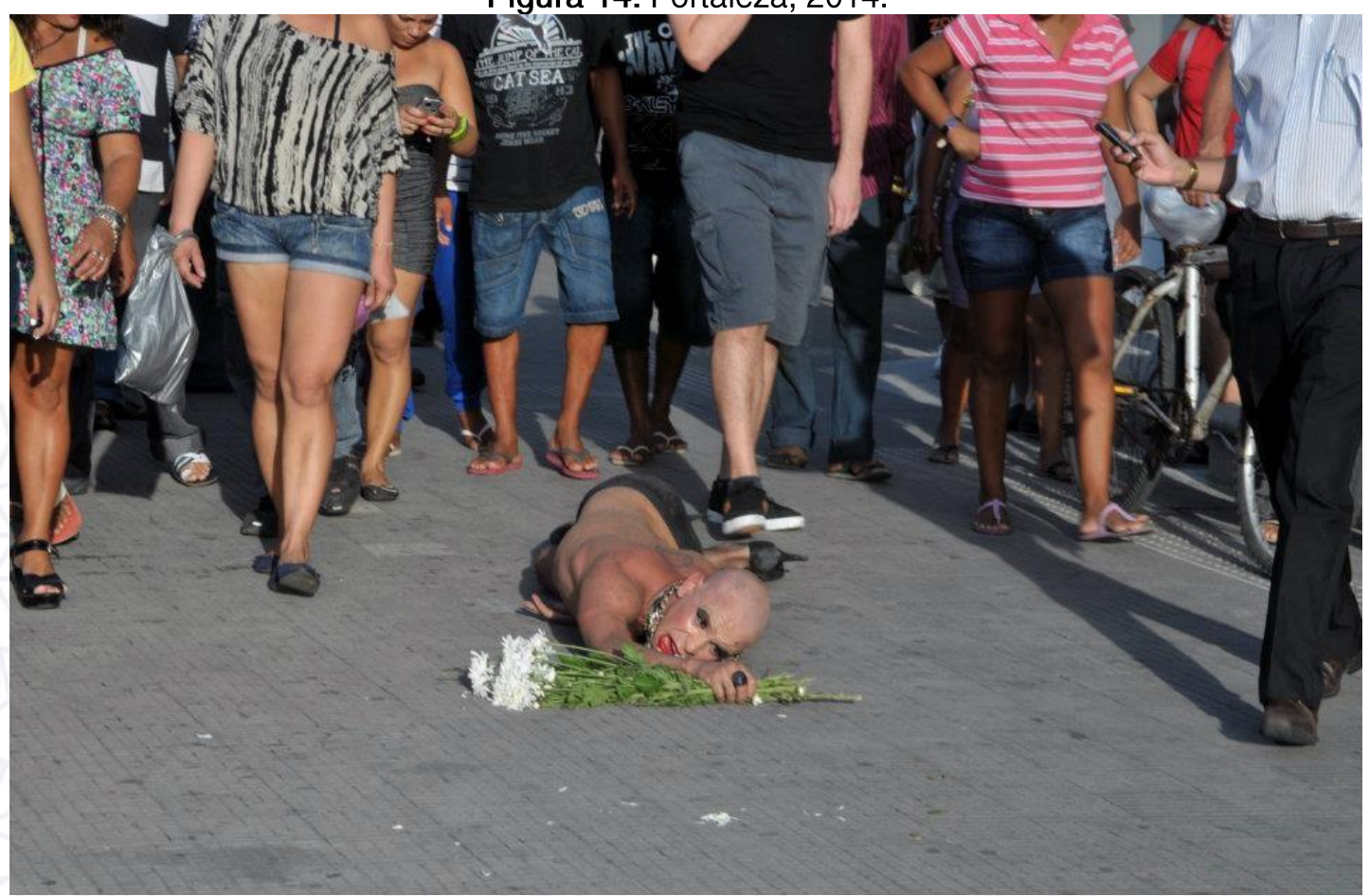

Foto de Marcelo Alasino. 
IV.

\section{(futuros transancestrais ressignificando a calçada)}

Como o movimento de uma célula em metástase, o corpo político de Princesa tensiona a recepção dos passantes, tomados nesta relação transitória como as demais células do mesmo tecido social corrompido. A cada avanço do percurso, meticulosamente "dançado", o corpo estaciona como em uma via-crúcis para ser novamente coisificado através do enxame de celulares ávidos a registrar o momento de uma beleza insólita que procura fixar-se através da imagem como documento da intolerância.

Não alimente os animais é um manifesto poético e radical contra toda e qualquer forma de totalitarismo. Irrompe no cotidiano das relações sociais reificadas consciente de que o movimento provém da margem, e que é nessa margem e não no centro que reside a possibilidade de transformação.

(Márcio MARCIANO, sobre Não alimente os animais, para o Festival Zona de transição) ${ }^{6}$

Hoje é 2021. E onze anos depois de estar naquele chão gelado chorando sem querer chorar, continuamos precisando abrir fendas em calçadas. Quando penso na realidade que vivemos continuo sentindo o cheiro de sangue das minhas amigas assassinadas, sinto a garganta embargar pensando nas vezes que estive no hospital com um amigo espancado, respiro fundo recuperando o fôlego como nas diversas vezes que corri na rua com medo de apanhar. Ou morrer. Ou ser estupradx. Lembro das vezes que sofri diversas violências caladx, achando que eu é que era a erradx, imersx numa estrutura estatal com dispositivos cuidadosamente pensados para garantir que eu me sentisse assim.

A maravilhosa Conceição Evaristo nos deixou de presente o mantra: "eles querem nos matar, mas nós combinamos que não vamos morrer", e agorinha a minha contemporânea Jota Mombaça complementou: "Não vão nos matar agora". Faço parte de uma enxurrada de corpos que existem desafiando o gênero binário e sua dinâmica compulsória. Uma horda que não tem medo de habitar o incerto, o pouco definido, o borrado, o estranho. Um enxame que não engole a pretensa verdade segundo a qual a humanidade é

\footnotetext{
${ }^{6}$ Disponível em:

$<$ http://www.fundacaoamigostheatrojosedealencar.org/announcements/cadernos-zona-cronicado-setimo-dia-por-marcio-marciano $>$
} 
dividida unicamente entre homens e mulheres. A corpa que sou hoje, vivendo no país que vivo hoje, não tem outra escolha a não ser atualizar criativa e diariamente suas estratégias de sobrevivência. Todos os dias preciso me perguntar o que estou fazendo para garantir que meu corpo não seja literalmente apedrejado na rua e minhas subjetividades não sejam violentadas na padaria, na internet, no congresso nacional, na universidade.

Mas é assim: cada vez que eu caio diante de um ignorante, toda vez que me tranco no quarto de medo, ou choro minutos a fio no chuveiro, o corro de alguém gargalhando seu poder. A cada uma das vezes que passo por uma situação dessas, saio uma Princesa ainda mais exuberante. No dia seguinte a gente troca o modelito, retoca a maquiagem e começa tudo de novo, pois como já disse a outra maravilhosa da Caio Fernando de Abreu, "Tem o seguinte, meus senhores: não vamos enlouquecer, nem nos matar, nem desistir. Pelo contrário: vamos ficar ótimos e incomodar bastante ainda." Tenho repetido isso como um mantra. Na vida, na dança, na calçada. 